\title{
A review on factors contributing to declining trade union membership in Malaysia
}

\author{
Jaya Ganesan * \\ Faculty of Business, Multimedia University, Jalan Ayer Keroh Lama 75450, Malacca, Malaysia
}

\section{A R T I C L E IN F O}

\section{Article history:}

Received 5 July 2016

Received in revised form

22 October 2016

Accepted 13 November 2016

\section{Keywords:}

Trade union membership

Trade union internal factors

Employer hostility

Industrial relations climate

\section{Introduction}

Trade unions are one of the key partners in the Malaysian industrial relations system. An understanding of the factors that influence the growth of union is vital because it has implications on the strength and effectiveness of unions. Labor legislations in Malaysia protect the rights of employers and employees in organizing and forming trade unions. This is evident through the Employment Act 1955, the Industrial Relations Act 1967 and the Trade Union Act 1959 (Tarumaraja et al., 2015). The number of trade unions in Malaysia is steadily increasing. However, the trade union membership is slowly declining. Many studies were conducted to examine the factors responsible for declining union membership (Ramasamy, 2010).

According to Gall and Fiorito (2012), when unions tend to be more effective and productive when thye have greater participation from members. Simms et al. (2012) stated that that unions have greater bargaining power when they have stronger membership. In the Malaysian context, there is undoubtedly pressure on unions emphasise on increasing their membership as they confront challenge of state/employer dominated industrial relations system (Kumar et al., 2013).However,

\footnotetext{
* Corresponding Author.

Email Address: jaya.ganesan@mmu.edu.my

https://doi.org/10.21833/ijaas.2016.11.015

2313-626X/C) 2016 The Authors. Published by IASE.

This is an open access article under the CC BY-NC-ND license

(http://creativecommons.org/licenses/by-nc-nd/4.0/)
}

according to Rose et al. (2011) the existence of unions at workplace has both positive and negative effects.

\subsection{Overview of trade union membership in Malaysia}

Table 1 provides statistics of trade unions and membership growth in Malaysia from 2006 to 2015. Trade union density changed from 7.18 in 2006 to $6.51 \%$ in 2011 and increased again in 2012 to $6.99 \%$. The average trade union density from 2006 to 2015 was $6.8 \%$. Membership growth rate was $1.26 \%$ in 2000 and $2.8 \%$ in 2013. However, the number of trade unions has steadily increased from 631 unions in the year 2006 to 706 unions in the year 2013.However, in 2014 the number of unions increased to 735 but in 2015 it decreased to 729 .

Taking Table 1 into perspective, the picture does not represent a healthy trend in the growth of unions. According to recent statistics there were 729 unions in Malaysia out of which 626 were in-house trade unions and 103 were national trade unions. This was another indication that Malaysian unions were in-house in nature, and in-house unions have their own advantages and disadvantages.

The growth and the density of the trade union membership has always been stagnant for an over a past few decades. Only 9\% of workers in Malaysia are unionized and this percentage has never been increased over the years despite the steady increase on population and the work opportunities in this country. Malaysian union membership growth rate had showed a decreasing trend despite increasing 
number of growth of registered union and employment in this country (Ramasamy, 2010; Kumar et al., 2013; Tarumaraja et al., 2015;
Aminuddin, 2013). The Department of Trade Union Affairs does not indicate the actual reasons for such an imbalance in the statistics.

Table 1: Trade union membership and trade union density

\begin{tabular}{|c|c|c|c|c|c|}
\hline Year & $\begin{array}{c}\text { Total Employment } \\
\text { ('000) }\end{array}$ & $\begin{array}{l}\text { Total Trade } \\
\text { Unions }\end{array}$ & $\begin{array}{c}\text { Total } \\
\text { Membership }\end{array}$ & $\begin{array}{c}\text { Average Members } \\
\text { per Union }\end{array}$ & $\begin{array}{c}\text { Union } \\
\text { Density (\%) }\end{array}$ \\
\hline 2006 & $10,275.4$ & 631 & 801585 & 1270 & 7.18 \\
\hline 2007 & $10,538.1$ & 642 & 803212 & 1251 & 7.05 \\
\hline 2008 & $10,659.6$ & 659 & 805565 & 1222 & 6.96 \\
\hline 2009 & $10,897.3$ & 680 & 806860 & 1186 & 6.94 \\
\hline 2010 & $11,899.5$ & 670 & 803289 & 1198 & 6.75 \\
\hline 2011 & $12,284.4$ & 697 & 800171 & 1148 & 6.51 \\
\hline 2012 & $12,723.2$ & 694 & 889718 & 1282 & 6.99 \\
\hline 2013 & $13,210.0$ & 706 & 914677 & 1295 & 6.92 \\
\hline 2014 & $13,852.0$ & 735 & 930512 & 1266 & 6.71 \\
\hline 2015 & $14,067.0$ & 729 & 913169 & 1252 & 6.49 \\
\hline
\end{tabular}

\section{Literature review}

\subsection{Trade union membership}

Trade unions represent workers' interests and rights at workplace. Unions play a significant role in collective bargaining and settlement of disputes. However, several studies report that there is a steady decline in the union density and union membership across the world. This scenario poses a serious challenge to unions in sustaining their existence as well as their role in industrial relations system. Several factors such as economy fluctuations, foreign direct investment, employer opposition, changes in employment conditions and patterns, human resource management practices, labor legislations affect the union membership and union strategies to a greater extent (Aminuddin, 2013; Benson and Zhu, 2008; Rose et al., 2011; Linda, 2012; Arthur and Gemma, 2014).

Table 2 indicates some of the previous studies on trade unionism and trade union membership in the Malaysian context.

Table 2: A brief review of literature on trade union growth and trade union membership

\begin{tabular}{|c|c|}
\hline Source & Contribution \\
\hline Anantaraman (2007) & $\begin{array}{l}\text { The study focused on how the industrial relations climate and the weakness of the trade } \\
\text { union movement in Malaysia are not hostile to foreign direct investment. }\end{array}$ \\
\hline Arudsothy and Littler (1993) & Role of state and union fragmentation \\
\hline Parasuraman (2004) & Growth of industrial relations and trade unions \\
\hline Bhopal (2001) & $\begin{array}{l}\text { Trade unions and political interventions } \\
\end{array}$ \\
\hline Fatima Said et al. (2002) & $\begin{array}{l}\text { Determinants of trade union membership in Malaysia: A new model of trade union } \\
\text { membership growth in Malaysia for the period 1970-2000 is proposed with special } \\
\text { focus on political factors. }\end{array}$ \\
\hline Jomo and Todd (1994) & Trade union development in Peninsular Malaysia. \\
\hline Kumar et al. (2013) & Structural barriers to trade union growth at workplace \\
\hline Kuruvilla $(1995,1996)$ & Stages of industrialization, industrial relations and trade unions in Malaysia. \\
\hline Aminuddin (2009) & Unions and employment relations in the private sector. \\
\hline Ramasamy (2010) & Actors' perceptions towards barriers of trade union growth. \\
\hline Rasiah (1995) & Industrialization and labor movement. \\
\hline Sharma (1989) & Economic factors and union growth in Malaysia and Singapore. \\
\hline
\end{tabular}

\subsection{Industrial relations climate}

Industrial relations climate describes how employees, employers and the union with the support of state coordinate with each other at workplace. The industrial relation climate is a crucial factor which influence employees work performance and also their effective participation at workplace. In the Malaysian context, industrial relation climate plays an important role in determining quality of work life (Nasurdin et al., 2006; Abdullah et al.,
2009; Qureshi et al., 2014). Some studies demonstrated that the industrial relation climate may influence the unions in a positive way to sustain their membership (Magenau et al., 1988; Dastmalchian, 2008; Snape and Redman, 2012). According to Pyman et al. (2010), industrial relations climate reflects the behaviour of people at workplace and also describes the relationship between employees, management and unions. Aminuddin (2013) stated that industrial relations climate is 
influenced by legislations and government regulations.

\subsection{Employer hostility}

Hyman (1989) stated that employees design the organisational culture or work culture which pose challenges to workers' collective identity with their unions. Gall and McKay (2001), Cullinane and Dundon (2012), Rose et al. (2011) argued that the degree of harmonious industrial relations depends upon the employer's acceptance or resistance of unions at workplace. Moreover, this directly influences the employees' decisions to join unions. According to Gall and McKay (2001) employers substitute the presence of unions with sophisticated human relations strategies. However, in the Malaysian context, where industrial relations system is said to be state dominated, employers delay union recognition without concrete reasons (Aminuddin, 2013; Ramasamy and Rowley, 2008). Malaysian employers have historically been viewed as less accommodative to unions (Kumar et al., 2013; Aminuddin, 2013).

\subsection{Trade union internal factors}

Union organizing is described as the ability of unions to attract and retain members (Fiorito and Jarley, 2003). According to Tarumaraja et al. (2015), there is a significant impact of union organizing on union effectiveness. Their study further reveals that union organizing also implies the capability of a union is achieving targeted goals set by visionary union leaders. This reflects the relationship between union organizing and union effectiveness. However, as stated by Ramasamy (2010) trade unions in Malaysia experience a demonstrating decline in union density. This indicates the fact that if unions are to be effective, unions should urge on setting goals that combat with social, economic and legal changes. Unions should also reconsider in reorganizing their structures, systems, leadership styles, and strategies in line with both national and international industrial relations systems (Fiorito and Jarley, 2003; Ganesan et al., 2015).

Union commitment can be divided into four different types such as loyalty to the union, responsibility toward the union, willingness to make a mental or physical effort on behalf the union, believing on the goal of union. It is also assumed that the value and the rationality based commitment can be a positive source of union membership but the members level of commitment may differ according to the culture, laws and industrial relations of each country (Johari, 2014). Union strategy has been recognized as one of the most important determinants of reviving unions from the density of memberships, legitimacy, and influence (Gahan and Bell, 1999; Satrya and Parasuraman, 2012). Union instrumentality is described as the belief that unions are able to provide a better economic security, quality work life and protect worker rights at work
(Bamberger et al., 1999). Union leadership refers to the ability of the union leaders to facilitate and encourage positive attitude towards union and its activities. This initiative by the leaders may assist union members in understanding the values, objectives and strategies of the union (Dhamika et al., 2013).

\section{Methodology}

Data for the study was collected through the survey method. A self-administered questionnaire was used as the research instrument in collecting data. The questionnaire was developed based on the literature review as stated below in Table 3. The respondents for the study were unionised employees who were members of the Malaysian Trade Union Congress representing five different sectors. These respondents were identified through purposive sampling. A total of 250 questionnaires were distributed and 237 questionnaires were collected.

\section{Results and discussion}

A total of 237 completed survey questionnaires were received. All questions tested were found to be reliable and valid. The reliability value was above 0.80 for all the variables. The descriptive analysis indicated that $63 \%$ of the respondents who participated in this survey were found to be in the age group of 35-44. A total of $89 \%$ of the respondents were diploma holders. Around 83\% were earning between RM 2,000-RM 3,000 and 37\% of the respondents represented the manufacturing sector. Around $90 \%$ of the respondents were male and in terms of race distribution $73 \%$ of the respondents were Malay.

The correlation analysis was conducted to test the relationship between factors (Trade Union Internal Factors, Employer Hostility, and Industrial Relations Climate) and trade union membership. The result is presented below.

All the three independent variables have a positive impact on declining trade union membership at 0.000 significant level. Therefore, it is evident that trade union internal factors, employer hostility, industrial relations climate have significant relationship with trade union membership (Table 4).

Next, multiple regression analysis is conducted to identify the predictors of declining trade union membership. Table 5 presents the multiple regression analysis results. The $r$ square value is 0.463 which indicates that $46.3 \%$ of the variation within the dependent variable could be explainable by the variation in the three independent variables. Furthermore, the $F$ value is 40.271 and the $p$ value is $0.000(\mathrm{p}<0.05)$. Therefore, it means that the at least one of the independent variables predicts the dependent variable (Table 5).

The coefficient analysis result is presented in Table 6. The significant value showed that all of the factors have $p$ value of below 0.05 . This means all the factors are predictors. The highest beta value is for 
industrial relations climate $(B=0.424)$. This indicates that industrial relations climate is the most significant influencing factor on trade union membership. This is followed by employer hostility $(B=0.399)$, and the lowest is for trade union internal factors $(B=0.132 ; \mathrm{p}<0.05)$.

Table 3: Sources of variables

\begin{tabular}{cc} 
Variable & Source \\
\cline { 2 - 2 } Trade Union Internal & $\begin{array}{c}\text { Satrya, 2010; Kumar et al., 2013; Johari, 2014; Fiorito and Jarley, 2003; } \\
\text { Factors }\end{array}$ \\
\cline { 2 - 2 } $\begin{array}{c}\text { Industrial Relations Climate } \\
\text { Employer Hostility }\end{array}$ & Snape and Redman, 2012; Pyman, 2004 \\
\cline { 2 - 2 } Union Membership & Campolieti et al., 2013; Gall and McKay, 2001; Cullinane and Dundon, 2012 \\
\hline
\end{tabular}

Table 4: Results of correlation analysis

\begin{tabular}{|c|c|c|}
\hline \multirow{2}{*}{ Independent Variables } & Dependent Variable & $\begin{array}{c}\text { Trade Union } \\
\text { Membership }\end{array}$ \\
\hline \multirow{2}{*}{ Industrial Relations Climate } & Pearson Correlation & .680 \\
\cline { 2 - 3 } & Sig. & .000 \\
\hline \multirow{2}{*}{ Employer Hostility } & Pearson Correlation & .750 \\
\cline { 2 - 3 } & Sig. & .000 \\
\hline \multirow{2}{*}{ Trade Union Internal Factors } & Pearson Correlation & .772 \\
\cline { 2 - 3 } & Sig. (2-tailed) & .000 \\
\hline
\end{tabular}

Table 5: Results of multiple regression analysis

\begin{tabular}{|c|c|c|c|c|c|}
\hline R & R Square & Adjusted R Square & Std. Error of the Estimate & \multicolumn{2}{c|}{ F } \\
\hline $.680^{\mathrm{a}}$ & .463 & .460 & .434 & 40.271 & 0.000 \\
\hline
\end{tabular}

Table 6: Coefficient table

\begin{tabular}{|c|c|c|c|c|c|}
\hline & \multicolumn{2}{|c|}{ Unstd Coefficients } & \multirow{2}{*}{$\begin{array}{c}\text { Std Coefficients } \\
\text { Beta }\end{array}$} & \multirow[b]{2}{*}{$\mathbf{t}$} & \multirow{2}{*}{ Sig. } \\
\hline & B & Std. Error & & & \\
\hline Constant & .138 & .309 & & .838 & .403 \\
\hline Trade Union Internal Factors & .132 & .055 & .421 & 2.395 & .000 \\
\hline Employer Hostility & .399 & .061 & .361 & 6.499 & .000 \\
\hline Industrial Relations Climate & .424 & .059 & .135 & 7.240 & .017 \\
\hline
\end{tabular}

The purpose of the study is to identify the factors that contribute towards the declining trade union membership. The study was conducted among unionized employees from five different sectors namely, telecommunication, manufacturing, health, transport and storage and services. They are considered appropriate to provide the information since they are unionized and members of the Malaysian Trade Union Congress and are well versed with industrial relations system and trade union activities. Therefore, they will be able to determine the factors contributing for decline in trade union membership and regarded suitable for this study.

Three factors were tested to identify which contributes to the decline of trade union membership and the finding reveals all the factors tested are contributors. Industrial relations climate is important to union membership because the government restricts the union rights in collective bargaining through a management prerogative clause under the Industrial Relations Act 1967. Further, the Trade Union Act 1959 also impose strict restrictions on union organising and union activities. This is supported by Baird and Lansbury (2007). Wad (2012) stated that some of the in-house unions are not capable of protecting employee rights at workplace.

Employers adopt intense union suppression or avoidance strategies and managerial tactics to diffuse union organising. This finding is supported by previous studies such as Logan (2006). Next, trade union internal factors such as the ability of the unions to organise, union instrumentality, union leadership and union commitment also influence the membership of trade unions. This is because especially in the Malaysian context without the approval of employers' trade unions cannot increase their membership and revitalise their strategies. However, unions do not take proactive measures to resolve this situation. Thus, Malaysian unions are unable to gain the confidence of members. This is supported by Kumar et al. (2013).

\section{Conclusion}

Globalization, employer supportive labor legislations, changing perceptions of employees towards their workplace make it difficult for unions to establish strong representation in many Malaysian workplaces at present than in early days. Malaysian Unions may continue to have constraints appealing to educated workers unless they continue to adapt to the changes of the labor market, particularly in light of challenges such as hostility from employers at workplace. The study's main limitation is the sample size. Future study should consider a higher number of respondents. Furthermore, union leaders can also be used as 
sample. Employers' viewpoint can be an area of study especially in the context of industrial relations climate and employer hostility. In addition, studies in future may include a set of other variables to determine declining trade union membership.

\section{Acknowledgement}

This study is undertaken under the Internal Grant Scheme 2016 provided by Multimedia University, Malaysia.

\section{References}

Abdullah NAC, Spickett JT, Rumckev KB, and Dhaliwal SS (2009). Validity and reliability of the safety climate measurement in Malaysia. International Review of Business Research Papers, 5(3): 111-141.

Aminuddin M (2009). Employment relations in Malaysia: past, present and future. New Zealand Journal of Asian Studies, 11(1): 304-317.

Aminuddin M (2013). Malaysian industrial relations and employment law. $8^{\text {th }}$ Edition, McGraw -Hill, Kuala Lumpur, Malaysia.

Arudsothy P and Littler C (1993). State regulation and fragmentation in Malaysia. In Frenkel S (Eds), Organised labor in the Asia- Pacific region: A comparative study of trade unions in nine countries. ILR Press, Ithaca, USA.

Baird M and Lansbury R (2007). Reworking or restoring the American dream. Labor History 48(3):347-354.

Bamberger PA, Kluger AN, and Suchard R (1999). The antecedents and consequences of union commitment: A meta-analysis. Academy of Management Journal, 42(3): 304 -318.

Benson J and Zhu Y (2008). Trade unions in Asia-An economic and sociological analysis. Routledge, London, UK.

Bhopal M (2001). 'Malaysian unions in political crisis: Assessing the impact of the Asian contagion. Asia Pacific Business Review, 8(2): 73100.

Campolieti M, Gunderson M, and GomezR (2013). Managerial hostility and attitudes towards unions: A Canada-US comparison. Journal of Labor Research, 34(1): 99-119.

Cullinane, N and Dundon T (2012). Unitarism and employer resistance to trade unionism. The International Journal of Human Resource Management, 25(18): 2573-2590.

Dastmalchian A (2008). Industrial relations climate. The SAGE Handbook of Industrial Relations. Sages Publications, Inc, California, USA.

Dhamika KAS, Ahmad F, and Sam TL (2013). Transactional, transformational, union and organizational commitment: An examination of the effect flaws. International Journal of Business and Social Sciences, 4(6): 103-111.

Fiorito J and Jarley P (2003). Union organizing commitment: rhetoric and reality. In the Proceedings of the $55^{\text {th }}$ Annual Meeting of the Industrial Relations Research Association, IRRA, Champaign, USA: 283-293.

Gahan P and Bell S (1999). Union strategy, membership orientation and union effectiveness: An exploratory analysis. Labour and Industry, 9(3): 5-30.

Gall G and Fiorito J (2012). Union commitment and activism in britain and the united states: Searching for synthesis and synergy for renewal. British Journal of Industrial Relations 50(2): 189213.

Gall G and McKay S (2001). Facing 'fairness at work': Union perception of employer opposition and response to union recognition. Industrial Relations Journal, 32(2): 94-113.

Hyman R (1989). Dualism and division in labour strategies. In Hyman R (Eds.), The Political economy of industrial relations. Macmillan, London, UK.

Jaya Ganesan, R.N.Anantharaman, Hishamuddin Bin Ismail, Issues of Trade Union Density: A Review. Aust. J. Basic \& Appl. Sci., 9(7): 35-40, 2015

Johari, H. (2014). Predictors of union commitment among the public sector employees. International Journal of Science and Research 3(6), 2515-2521.

Jomo KS and Todd P (1994). Trade unions and the state in Peninsular Malaysia, Oxford University Press, Kula Lumpur, Malaysia.

Kumar N, Lucio MM, and Rose RC (2013). Workplace industrial relations in a developing environment: Barriers to renewal within unions in Malaysia. Asia Pacific Journal of Human Resources, 51: 2244.

Kuruvilla S (1995). Industrialisation strategy and industrial relations policy in Malaysia. In Frenkel $\mathrm{S}$ and Harrod J (Eds.), Industrialisation and labour relations: Contemporary research in seven countries: 36-66. ILR Press, Ithaca, USA.

Kuruvilla S (1996). The relationship between economic development strategies and industrial relations: India, Malaysia, Singapore and the Philippines. Industrial and Labor Relations Review, 49(4): 635-657.

Linda D (2012). Making employment rights effective: issues of enforcement and compliance. Hart Publishing, Oxford, UK.

Magenau JM, Martin JE, and Peterson MM (1988). Dual and unilateral commitment among stewards and rank-and-file members. Academy of Management Journal, 31(2): 359-376. 
Nasurdin AM, Ramayah T, and Chee Beng Y (2006). Organizational structure and organizational climate as potential predictors of job stress: Evidence from Malaysia. International journal of commerce and management, 16(2): 116-129.

Parasuraman B (2004) Malaysian industrial relations: A critical analysis. Pearson Prentice Hall, Kuala Lumpur, Malaysia.

Pyman A (2002). Union effectiveness: Theorising a set of dimensions union effectiveness. In the $16^{\text {th }}$ AIRAANZ Conference, Queenstown, New Zealand.

Pyman A (2004). Union rights of entry: The new contested terrain?. In the Proceedings of Association of Industrial Relations Academics of Australia and New Zealand Conference, Noosa, Australia.

Pyman A, Holland P, Teicher J, and Cooper BK (2010). Industrial relations climate, employee voice and managerial attitudes to unions: An Australian study. Journal of Industrial Relations, 48(2): 460-480

Qureshi MI, Rasli AM, and Zaman K (2014). A new trilogy to understand the relationship among organizational climate, workplace bullying and employee health. Arab Economic and Business Journal, 9(2): 133-146.

Ramasamy N (2010). Perceived barriers to trade unionism in Malaysia. Ph.D. Dissertation, University Putra Malaysia.

Ramasamy N and Rowley C (2008). Trade unions in Malaysia: Complexity of a state-employer system. In Benson J and Zhu Y (Eds.), Trade unions in Asia: An economic and sociological analysis. Routledge, London, UK.

Rasiah R (1993). Free trade zones and industrial development in Malaysia. In Jomo KS (Eds.), Industrilising Malaysia: Policy, performance, prospects. Routledge, London, UK.
Rose RC, Kumar N, and Ramasamy N (2011). Trade unions in Malaysia: perspectives of employers and employees of unionized companies. Indian Journal of Industrial Relations, 46(3): 384-395.

Said F, Zakaria RH, and Said SM (2002). The determinants of trade union membership growth in Malaysia. International Journal of Economics, Management and Accounting, 10(2): 1-17.

Satrya A (2010). Effective union strategy in developing countries: Lessons from Indonesian enterprise unions. Lap Lambert Academic Publishing, Saarbrücken, Germany.

Satrya A and Parasuraman B (2012). Multidimensional approach to union effectivenesscase studies from Indonesia \& Malaysia. The Indian Journal of Industrial Relations, 47(2): 219234.

Saundry R and Wibberley G (2013). Contemporary union organizing in the UK-Back to the future? Labor Studies Journal, 38(4): 281-299.

Sharma B (1989). Union growth in Malaysia and Singapore. Industrial Relations, 28(3): 446-458.

Simms M, Holgate J, and Heery E (2012). Union voices: Tactics and tensions in UK organizing. Cornell University Press, Ithaca, USA.

Snape ED and Redman T (2012). Industrial relations climate and union commitment: An evaluation of workplace-level effects. Industrial Relations: A Journal of Economy and Society, 51(1): 11-28.

Tarumaraja BA, Omar F, Halim FW, and Hafidz SWM (2015). The Relationship between union organization and union effectiveness: The role of type of union as moderator. Procedia-Social and Behavioral Sciences, 211: 34-41.

Wad P (2012). Revitalizing the Malaysian trade union movement: The case of the electronics industry. Journal of Industrial Relations, 54(4): 494-509. 